\title{
Incidence of Pectolytic Erwinias Associated with Blackleg of Potato in Rio Grande do Sul ${ }^{1}$
}

\author{
Andréia M. R. Oliveira², Valmir Duarte, José R. P. Silveira \& Marcelo G. Moraes \\ Departamento de Fitossanidade, Faculdade de Agronomia, Universidade Federal do Rio Grande do Sul, Cx. Postal 776, \\ CEP 90001-970, Porto Alegre, RS, Phone/fax: +55 51 3316-6016, e-mail:valmir@ufrgs.br
}

(Accepted for publication on 31/10/2002)

Author for correspondence: Valmir Duarte

OLIVEIRA, A.M.R., DUARTE, V., SILVEIRA, J.R.P. \& MORAES, M.G. Incidence of pectolytic erwinias associated with blackleg of potato in Rio Grande do Sul. Fitopatologia Brasileira 28:049-053. 2003.

\begin{abstract}
Erwinia carotovora subsp. atroseptica (Eca), E. carotovora subsp. carotovora (Ecc) and E. chrysanthemi (Ech) may cause potato (Solanum tuberosum) blackleg. To determine the occurrence of these pathogens in the conditions found in the State of Rio Grande do Sul (RS), potato plants showing blackleg symptoms were harvested from 22 fields in nine counties in Serra do Nordeste, Planalto, Depressão Central, and Grandes Lagoas, from September to December of 1999 (Spring-Summer season). Green pepper (Capsicum annuum) fruits were used as a host to enrich for pectolytic erwinia from potato stems with blackleg symptoms. Bacteria were subsequently isolated on non-selective medium.

Isolates that were Gram-negative, facultatively anaerobic, and pitted crystal-violet-pectate medium were tested for biochemical traits to identify the species and subspecies. Four hundred strains were identified as either Eca, Ecc or Ech. Although the three erwinias were found in RS potato fields, only three strains of Ech were found in one field. Frequencies of Eca and Ecc were 55 and $42 \%$, respectively. Eight strains could not be assigned based on the biochemical characterization.

Additional key words: Erwinia carotovora subsp. atroseptica, E. carotovora subsp. carotovora, Erwinia chrysanthemi, epidemiology, Solanum tuberosum, soft rot.

\section{RESUMO}

Incidência de erwinias pectolíticas associadas com a canela preta em batata no Rio Grande do Sul

Erwinia carotovora subsp. atroseptica (Eca), E. carotovora subsp. carotovora (Ecc) e E. chrysanthemi $(\mathrm{Ech})$ podem causar canela preta em batata (Solanum tuberosum). Com o objetivo de verificar a ocorrência destes patógenos em lavouras do Rio Grande do Sul, plantas com sintomas de canela preta foram coletadas em 22 lavouras em nove municípios de quatro regiões produtoras: Serra do Nordeste, Planalto, Depressão Central e Grandes Lagoas, nos meses de setembro a dezembro de 1999 (safra primavera-verão).

Frutos de pimentão verde foram inoculados com palito de dente previamente espetados em tecido doente na haste de batata. Isolados com células Gram negativas, anaeróbios facultativos, formando cavidade em meio cristal-violeta pectato, foram identificados ao nível de espécie e subspécie através das características bioquímicas. Quatrocentos isolados foram identificados como Eca, Ecc ou Ech. Embora as três erwinias estejam presentes no RS, apenas três estirpes de Ech foram encontradas numa lavoura; as frequências de Eca e Ecc foram 55 e $42 \%$, respectivamente. Oito isolados não se ajustaram na classificação baseada nas características bioquímicas.
\end{abstract}

\section{INTRODUCTION}

Blackleg is endemic wherever potato (Solanum tuberosum L.) is grown in Brazil, but there are few reports (Jabuonski et al., 1986b) about the causal agent and its incidence. Erwinia carotovora subsp. atroseptica (van Hall) Dye (Eca) has been cited as the exclusive causal agent in cool and temperate regions. However, E. carotovora subsp. carotovora (Jones) Bergey et al. (Ecc) and E. chrysanthemi Burkholder et al. (Ech) can also cause similar symptoms (Gumestad \& Secor, 1993; Duarte, 1999).

Identification of Eca, Ecc and Ech is based on biochemical and phenotypic characteristics (Pérombelon \&

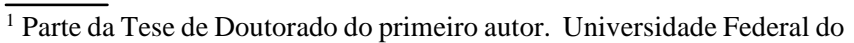
Rio Grande do Sul. (2001)

${ }^{2}$ Bolsista do CNPq
}

Hyman, 1986; Dickey \& Kelman, 1988; Hyman et al., 1998). Serology (De Boer \& McNaughton, 1987; Singh et al., 2000) and, more recently, molecular techniques (De Boer \& Ward, 1995; Helias et al., 1998; Fréchon et al., 1998) have also been applied.

Ecological and epidemiological studies of these pathogens have shown Eca, Ecc and Ech to have a wide geographical distribution, correlated with temperature, and host range (Pérombelon \& Kelman, 1980). Diversity within Ecc and Ech is far greater than that within Eca, making it possible to relate diversity within Ech and, to a lesser degree, Ecc with host range and geographical location. Ecc occurs in regions with different temperatures, in soil and in surface water of lakes, rivers and oceans, and in the rhizosphere of host and nonhost plants (Pérombelon \& Kelman, 1980). Ech is pathogenic to many important crop and ornamental plants 
A.M.R. Oliveira et al.

in tropical and subtropical climates, but is composed of strains that show some host specificity (Jabuonski et al., 1986a).

Few epidemiological studies involving species and subspecies identification of Erwinia affecting potatoes have been done in subtropical and tropical climates, such as Brazil. Most publications are reports of occurrence of Ecc (Takatsu, 1983). Jabuonski et al. (1986a) assessed species of pectolytic erwinias in several hosts, including potato, and found that Ecc was predominant in nine out of ten states of Brazil. Only Eca was isolated from potato in Rio Grande do Sul. Other references to the occurrence of Eca were made by Robbs (1981) and Silveira (1992).

Control of blackleg is based on crop management practices such as crop rotation, elimination of plant debris, and use of pathogen-free seed tubers (Gumestad \& Secor, 1993). As Eca, Ecc and Ech have different survival mechanisms and host ranges, knowledge of the etiology of blackleg is necessary to establish suitable control measures. The objective of this study was to identify the species and subspecies of Erwinia associated with blackleg in potato fields of Rio Grande do Sul in order to evaluate local disease management strategies.

\section{MATERIALS AND METHODS}

\section{Sampling and isolation of pectolytic erwinias}

Plants showing blackleg symptoms were collected during September through December of 1999. Twenty samples were collected per field from 22 potato fields in nine counties, in four regions of RS: Serra do Nordeste, Planalto Superior, Depressão Central and Grandes Lagoas (Figure 1).

In the lab, toothpicks were stabbed into the margin of blackleg lesions in potato stems and then placed into surfacedisinfested (alcohol 70\%, $30 \mathrm{~s}$; $\mathrm{NaOCl} 1 \%, 30 \mathrm{~s}$; and washed with sterile distilled water) green pepper (Capsicum annuum L.) fruits (Takatsu et al., 1981). The inoculated fruits were kept in a humid chamber at $28^{\circ} \mathrm{C}$ for $24-48 \mathrm{~h}$. Decayed tissue was peeled off with a scalpel. A loopful was used to touch the tissue and to streak the surface of K \& H 523 culture medium (Kado \& Heskett, 1970). Single colonies were harvested and tested for identity. Gram negative, facultatively anaerobic (Oxidation/Fermentation positive), straight rod-shaped bacteria, forming cream opaque colonies with irregular borders were considered to belong to the soft rot group of bacteria of the genus Erwinia (Dickey \& Kelman, 1988; Hyman et al., 1998). One bacterial isolate per plant was maintained in filter paper at $4{ }^{\circ} \mathrm{C}$ (Takatsu, 1970) and glycerol-water $(15: 85)$ at $-80{ }^{\circ} \mathrm{C}$.

\section{Biochemical tests}

Bacterial isolates were tested for production of reducing substances from sucrose and acid production from a-methyl-glucoside, maltose $\mathrm{D}(+)$, and lactose, growth at 37 ${ }^{\circ} \mathrm{C}$, and sensitivity to erythromycin (Dickey \& Kelman, 1988). Reference strains of E. carotovora subsp. atroseptica (Eca IBSBF 839), E. carotovora subsp. carotovora (Ecc IBSBF
1023 ) and $E$. chrysanthemi (Ech IBSBF 231), from the culture collection of Instituto Biológico, São Paulo, SP, Brazil, were used in each test.

Culture medium (peptone, $10 \mathrm{~g}$; bromocresol purple $1.5 \%, 0.7 \mathrm{ml}$; agar, $0.3 \mathrm{~g}$; sugar 10\%, $100 \mathrm{ml} / \mathrm{l}, \mathrm{pH} 6.8$ ) (Dickey \& Kelman, 1988) with each sugar was loaded in 96well microtiter plates. Bacteria from 24-48 h-old colonies were transferred to test media with a sterile toothpick, and incubated at $28{ }^{\circ} \mathrm{C}$. Results were recorded for two-seven days after inoculation. A color change from purple to yellow was considered positive. The tests were conducted twice.

\section{RESULTS AND DISCUSSION}

\section{Identification of pectolytic erwinias}

Four hundred and eight isolates of pectolytic erwinias were obtained from plants showing blackleg symptoms in potato fields in the four main production areas of RS. Among these, 224 isolates were determined to be Eca, 173 to be Ecc and three to be Ech (Table 1). Eight isolates presented traits that did not correspond to those of any of the three species and subspecies and thus were not identified. Ninety and $79 \%$ of the Eca and Ecc strains, respectively, did not produce acid from maltose. According to Lelliot \& Dick (1984), 21-79\% of $E$. carotovora strains should be positive. This behavior may indicate a striking difference between the Brazilian and the other strains. Ninety-two percent of Eca and $75 \%$ of Ecc produced acid from lactose, which is consistent with the

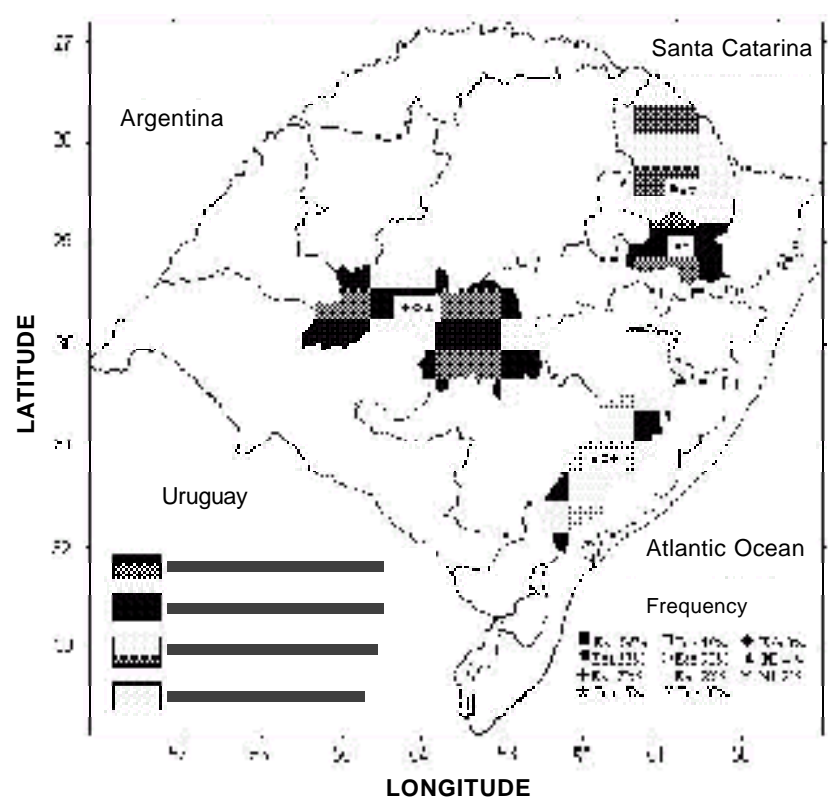

FIG. 1 - Agroecological regions of the State of Rio Grande do Sul where plants showing blackleg symptoms were collected from potato (Solanum tuberosum) fields. Frequency of Erwinia carotovora subsp. atroseptica (Eca), E. carotovora subsp. carotovora (Ecc) and E. chrysanthemi (Ech) in each region is indicated 
Incidence of pectolytic erwinias associated with blackleg of potato...

TABLE 1 - Physiological and biochemical tests of 400 pectolytic erwinias isolated from plants showing blackleg symptoms sampled from 22 potato (Solanum tuberosum) fields in the State of Rio Grande do Sul

\begin{tabular}{|c|c|c|c|c|c|c|c|c|c|}
\hline \multirow{3}{*}{$\begin{array}{l}\text { Species and } \\
\text { subspecies }\end{array}$} & \multirow{3}{*}{$\begin{array}{l}\text { Number } \\
\text { of strains }\end{array}$} & \multicolumn{8}{|c|}{ Strains (\%) } \\
\hline & & \multirow[b]{2}{*}{$\begin{array}{l}\text { Pectolytic } \\
\text { activity }\end{array}$} & \multirow[b]{2}{*}{$\mathbf{O} / \mathrm{F}^{*}$} & \multirow[b]{2}{*}{$\begin{array}{l}\text { Growth } \\
\text { at } 37^{\circ} \mathrm{C}\end{array}$} & \multirow[b]{2}{*}{$\begin{array}{l}\text { Resistance to } \\
\text { erythromycin }\end{array}$} & \multirow{2}{*}{$\begin{array}{c}\text { Produced reducing } \\
\text { substances from } \\
\text { sucrose } \\
\end{array}$} & \multicolumn{3}{|c|}{ Acid from } \\
\hline & & & & & & & $\begin{array}{l}\alpha \text {-methyl } \\
\text { glucoside }\end{array}$ & Lactose & Maltose \\
\hline Eca** $^{*}$ & 224 & 100 & 100 & 10 & 0 & 100 & 100 & 92 & 10 \\
\hline Ecc & 173 & 100 & 100 & 100 & 0 & 0 & 0 & 75 & 21 \\
\hline Ech & 3 & 100 & 100 & 100 & 100 & 0 & 0 & 0 & 0 \\
\hline
\end{tabular}

subspecies descriptions (Lelliot \& Dickey, 1984).

Acid production from $\alpha$-methyl-glucoside and growth at $37{ }^{\circ} \mathrm{C}$ are among the most important biochemical and physiological characteristics that differentiate Eca from Ecc (Pérombelon \& Kelman, 1980; Jabuonski et al., 1986a). However, there are conflicting data in the literature regarding the ability of Ecc to grow at $37{ }^{\circ} \mathrm{C}$ (Lelliot \& Dickey, 1984; Jabuonski et al., 1986a; Pérombelon \& Kelman, 1980; Hyman et al., 1998).

In the current study, none of the strains identified as Ecc produced acid from $\alpha$-methyl-glucoside but all grew at $37^{\circ} \mathrm{C}$, consistent with current description (Dickey \& Kelman, 1988). Among the strains collected from the different regions of Brazil by Jabuonski et al. (1986a), 44 were considered Ecc and did not grow at $37^{\circ} \mathrm{C}$. This was not confirmed here (Table 1). Phenotypic variability was observed among Ecc strains occurring in Brazil.

Among Eca strains, $10 \%$ grew at $37{ }^{\circ} \mathrm{C}$ in $24 \mathrm{~h}$ (Table 1), which is characteristic of Ecc and Ech. These strains might be atypical Eca, similar to those reported by other authors (Thomson et al., 1981; Helias et al., 1998).

Eight isolates did not fit into any identification profile. The occurrence of intermediate forms of Eca, Ecc and Ech, sharing common characteristics, has been reported (Thomson et al., 1981; Jabuonski et al., 1986a, 1986b). Thomson et al. (1981) described E. carotovora subsp. betavasculorum (Ecb), which occurs in sugar beet (Beta vulgaris L.), sunflower (Helianthus annuus L.), artichoke (Cynara cardunculus L.) and potato (Samson et al., 1998, cited by Helias et al., 1998), showing common characteristics with Eca and Ech. Therefore, the identity of these isolates should be investigated further, to see if they correspond to Ecb.

Polymerase Chain Reaction (PCR), using the primers ECA 1f and ECA 2r (De Boer \& Ward, 1995) and Y45 and Y46 (Fréchon et al., 1998), specific to Eca, amplified DNA from a control Eca strain (Eca 31 provided by S. H. De Boer, Center for Animal and Plant Health, Charlottetown, Canada), but did not amplify DNA from any of the strains identified as Eca in the current study (data not shown).

\section{Incidence and distribution of pectolytic erwinias}

Eca was prevalent in all geographic regions of RS, except Grandes Lagoas, where $90 \%$ of the strains were identified as Ecc and 5\% as Ech (Table 2). Since temperatures in RS are lower than most of the other states, the frequent occurrence of Ecc ( $42 \%$ of strains) may be considered unexpectedly high.

The association of Eca, Ecc or Ech with blackleg of potato is related to the environmental conditions, particularly temperature (Pérombelon \& Kelman, 1980; Pérombelon et al., 1979; Powelson, 1980). The distribution of Eca, Ecc and Ech in RS has no apparent relation to geographic region or temperature. A much higher incidence of Eca than Ecc would be expected in Serra do Nordeste, where temperatures are lower than in other regions (Table 2).

Rio Grande do Sul is characterized by a humid subtropical climate. The four potato production areas (Figure 1) are located in very distinct regions based on type of soil, temperature, and amount of rain. The results showed that these conditions favored a balanced incidence of Eca $(55 \%)$ and Ecc (42\%), but very low incidence of Ech (3\%) (Table 2). Based on studies of population dynamics, Pérombelon $e t$ al. (1979) suggested that, when both Eca and Ecc are present, Eca predominates at low temperatures $\left(16^{\circ} \mathrm{C}\right)$, and Ecc at high temperatures $\left(26^{\circ} \mathrm{C}\right)$. The populations are similar at 22 ${ }^{\circ} \mathrm{C}$. The study of seasonal incidence of Eca and Ecc in potato plants with blackleg symptoms in Oregon, U.S.A., at temperatures of 16 to $22{ }^{\circ} \mathrm{C}$, showed that both subspecies were associated with the disease and Eca and Ecc predominated in cooler and warmer seasons, respectively (Powelson, 1980).

Temperature was not associated with the predominance of Ecc (90\%) in the region of Grandes Lagoas (Table 2). This suggests that other epidemiological factors, like contaminated soil or seed potato, are involved. Powelson \& Apple (1984) studied the importance of soil as an inoculum source through the identification of serogroups of strains found in the soil and in blackleg infected tissues. They concluded that the possibility of contamination through the soil was low. Besides contaminated soil, such factors as potato seed, other host plants, insects, weed rhizosphere, and irrigation water must be considered to explain the survival and dissemination of Ecc (Armond et al., 1995). Therefore, the source of the inoculum for contamination of potatoes in Grande Lagoas may be primarily the seed tuber. The seed produced outside this region and the erwinia contamination may reflect the 
A.M.R. Oliveira et al.

TABLE 2 - Incidence of pectolytic erwinias associated with blackleg in 22 potato (Solanum tuberosum) fields in four production areas in the State of Rio Grande do Sul. 1999

\begin{tabular}{|c|c|c|c|c|c|c|c|c|}
\hline \multirow{3}{*}{ Region } & \multirow{3}{*}{ County } & \multicolumn{7}{|c|}{ Number of isolates } \\
\hline & & \multicolumn{3}{|c|}{ Potato field } & \multicolumn{4}{|c|}{ Identification } \\
\hline & & 1 & 2 & 3 & Eca* $^{*}$ & Ecc & Ech & NI \\
\hline \multirow{4}{*}{$\begin{array}{l}\text { Serra do Nordeste } \\
\left(17.1^{\circ} \mathrm{C}\right)^{* *}\end{array}$} & Caxias do Sul & $20^{\mathrm{Ba}^{* * *}}$ & 0 & 0 & 15 & 5 & 0 & 0 \\
\hline & Farroupilha & $20^{\mathrm{Ma}}$ & $12^{\mathrm{Ma}}$ & 0 & 12 & 20 & 0 & 0 \\
\hline & Garibaldi & $20^{\mathrm{Ma}}$ & 0 & 0 & 12 & 8 & 0 & 0 \\
\hline & $(\%)$ & & & & 54 & 46 & $\mathbf{0}$ & $\mathbf{0}$ \\
\hline \multirow{4}{*}{$\begin{array}{l}\text { Planalto Superior } \\
\left(19.0^{\circ} \mathrm{C}\right)\end{array}$} & Ibiraiaras & $20^{\mathrm{Ba}}$ & $16^{\mathrm{Ma}}$ & $20^{\mathrm{EI}}$ & 30 & 26 & 0 & 0 \\
\hline & Nova Prata & $20^{\mathrm{Ag}}$ & $20^{\mathrm{Ma}}$ & $17^{\mathrm{As}}$ & 49 & 5 & 0 & 3 \\
\hline & São Jorge & $20^{\mathrm{Ma}}$ & $18^{\mathrm{El}}$ & $20^{\mathrm{Ma}}$ & 30 & 25 & 0 & 3 \\
\hline & $(\%)$ & & & & 63 & 33 & $\mathbf{0}$ & 4 \\
\hline \multirow{3}{*}{$\begin{array}{l}\text { Depressão Central } \\
\left(20.4{ }^{\circ} \mathrm{C}\right)\end{array}$} & Santa Maria & $20^{\mathrm{Ba}}$ & $20^{\mathrm{Ma}}$ & $20^{\mathrm{Ba}}$ & 38 & 20 & 0 & 2 \\
\hline & Silveira Martins & $15^{\mathrm{Ma}}$ & $20^{\mathrm{Ma}}$ & $10^{\mathrm{Ba}}$ & 35 & 10 & 0 & 0 \\
\hline & $(\%)$ & & & & 70 & 28 & $\mathbf{0}$ & 2 \\
\hline \multirow{2}{*}{$\begin{array}{l}\text { Grandes Lagoas } \\
\left(18.8^{\circ} \mathrm{C}\right)\end{array}$} & São Lourenço do Sul & $20^{\mathrm{Ma}}$ & $20^{\mathrm{Ma}}$ & $20^{\mathrm{Sa}}$ & 3 & 54 & 3 & 0 \\
\hline & $(\%)$ & & & & 5 & 90 & 5 & $\mathbf{0}$ \\
\hline \multirow{2}{*}{\multicolumn{2}{|c|}{$\begin{array}{l}\text { Total } \\
(\%)\end{array}$}} & & 408 & & 224 & 173 & 3 & 8 \\
\hline & & & & & 55 & 42 & 1 & 2 \\
\hline
\end{tabular}

area where the seed was produced more than where the crop was sampled.

Considering that Ech is better adapted to warm regions than Eca or Ecc (Pérombelon \& Kelman, 1980), the low incidence (1\%) was expected. However, the occurrence of Ech associated with blackleg at $20{ }^{\circ} \mathrm{C}$ in Brazil was previously reported (Jabuonski et al., 1986b).

Eight strains out of 408 could not be identified in this study by the biochemical and physiological tests used. Jabuonski et al. (1986b) reported that four out of 22 isolates from potato blackleg in RS could not be identified. Also, Silveira (1992) reported on 23 isolates that did not fit in any of the Erwinia species or subspecies. The consistent presence of strains with traits that do not fit in the identification profile may show the variability of Brazilian strains. The identification and epidemiological importance of such strains need to be studied.

Besides the previous reports (Jabuonski et al., 1986b; Silveira, 1992), this is the first broad survey of pectolytic erwinias associated with potato blackleg in RS. It was shown that Ecc was associated with potato blackleg as frequently as Eca. Therefore, the management of this disease in RS must take into consideration the wider host range and the different ability of Ecc to survive in the environment. Epidemiological studies are crucial to establish the incidence of these subspecies in or on seed potatoes under local conditions.

\section{ACKNOWLEDGEMENTS}

The authors would like to thank the Instituto Biológico de Campinas (SP) for reference strains and S.H. De Boer from Canadian Food Inspection Agency, Canada, for Eca 31 DNA.

\section{LITERATURE CITED}

ARMOND, R., DOSORETZ, C., YORISH, A. SHELEF, G. \& NEEMAN, I. Survival of the pathogen Erwinia carotovora subsp. carotovora in sterile and non-sterile soil, sand and their mixture. Journal of Applied Bacteriology 79:513-518. 1995.

DE BOER, S.H. \& McNAUGHTON, M. E. Monoclonal antibodies to lipopolysaccharide of Erwinia carotovora subsp. atroseptica serogroup I. Phytopathology 77:828-832. 1987.

DE BOER, S.H. \& WARD, L.J. PCR detection of Erwinia carotovora subsp. atroseptica associated with potato tissue. Phytopathology 85:854-858. 1995.

DICKEY, R.S. \& KELMAN, A. Erwinia: "Carotovora" or soft rot group. In: Laboratory Guide for Identification of plant pathogenic bacteria.p. Schaad, N.W. 2 ed. St. Paul: APS. 1988. pp.44-59.

DUARTE, V. Taxonomia do gênero Erwinia. Revisão Anual de Patologia de Plantas 7:197-212. 1999.

FRÉCHON, D., EXBRAYAT, P., HELLAS, V., HYMAN, L.J., JOUAN, B., LLOP, P., LOPEZ, M.M., PAYET, N., PÉROMBELON, M.C.M., TOTH, I.K., VAN BECKHOVEN, R.C.M., VAN DER WOLF, J.M. \& BERTHEAU, Y. Evaluation of a PCR kit for the detection of Erwina carotovora subsp. atroseptica on potato tubers. Potato Research 41:163-173. 1998.

GUDMESTAD, N. \& SECOR, G. Management of soft rot and ring rot. In: Rowe R.R. (Ed.) Potato Health Management. APS. St. Paul. 1993.

HÉLIAS, V., LE ROUX, A. \& BERTHEAU, Y.et al. Characterisation of Erwinia carotovora subespecies and detection of Erwinia carotovora subsp. atroseptica in potato plants, soil and water extracts with PCR-based methods. European Journal of Plant Pathology 104:685-699. 1998.

HYMAN, L.J., TOTH, I.K. \& PÉROMBELON, M.C.M. Isolation and identification In: Pérombelon, M.C.M. \& Van Der Wolf, J.M. (Eds.). Methods for the detection and quantification of Erwinia 
Incidence of pectolytic erwinias associated with blackleg of potato...

carotovora subsp. atroseptica on potatoes. Laboratory Manual. Invergowrie. Scottish Crop Research Institute. 1998. pp. 60-65.

JABUONSKI, R.E., TAKATSU, A. \& REIFSCHNEIDER, F.J.B. Avaliação da patogenicidade de bactérias do gênero Erwinia isoladas de batateira, tomateiro e de outras plantas hospedeiras. Fitopatologia Brasileira 11:587-597. 1986a.

JABUONSKI, R.E., TAKATSU, A. \& REIFSCHNEIDER, F.J.B. Levantamento e identificação de espécies de Erwinia de diferentes plantas hospedeiras e regiões do Brasil. Fitopatologia Brasileira 11:185-195. 1986b.

KADO, C.J. \& HESKETT, M.G. Selective media for isolation of Agrobacterium, Corynebacterium, Erwinia, Pseudomonas and Xanthomonas. Phytopathology 60:969-976. 1970.

LELLIOTT, R.A. \& DICKEY, R.S. Genus VII. Erwinia Winslow, Brodahurst, Buchanan, Krumwiede, Rogers and Smith 1920. In: Krieg, N.R. \& Holt, J.G. (Eds.). Bergey's Manual of Systematic Bacteriology. Baltimore, Williams \& Wilkins. 1984. pp. 469-476. PÉROMBELON, M.C.M., GULLINS-HANDLEY, J. \& KELMAN, A. Population dynamics of Erwinia carotovora and pectolytic clostridia in relation to decay of potatoes. Phytopathology 69:167173. 1979.

PÉROMBELON, M.C.M. \& KELMAN, A. Ecology of the soft-rot Erwinia. Annual Review of Phytopathology 12:361-387. 1980.

PÉROMBELON, M.C.M. \& HYMAN, L.J. A rapid method to identify and quantify soft rot erwinias directly from plant material based on their temperature tolerance and sensitivity to erythromycin. Journal of Applied Bacteriology 60:61-66. 1986.

POWELSON, M.L. Seasonal incidence and cause of blackleg and stem soft rot of potatoes in Oregon. American Potato Journal 57:301306. 1980.

POWELSON, M.L. \& APPLE, J. Soil and seed tubers as sources of inoculum of Erwinia carotovora pv. carotovora for stem soft rot of potatoes. Phythopathology 74:429-432. 1984.

ROBBS, C.F. Taxonomia, bio-ecologia e principais representantes do gênero Erwinia no Brasil. Fitopatologia Brasileira 6:304-305. 1981.

SILVEIRA, J.R.P. Produção e utilização de anti-soros na diagnose de Erwinia carotovora (Jones) Bergey et al. subsp. atroseptica (Van Hall) Dye, E. carotovora (Jones) Bergey et al. subsp. carotovora (Jones) Dye e E. chrysanthemi (Bulkholder, McFadden \& Dimock). (Dissertação de Mestrado) Pelotas, RS. Universidade Federal de Pelotas. 1992.

SINGH, U., TREVORS, C.M. \& DE BOER, S.H. Fimbrial-specific monoclonal antibody-based ELISA for european potato strains of Erwinia chrysanthemi and comparison to PCR. Plant Disease 84:443-448. 2000.

TAKATSU, A. Preservação de bactérias fitopatogênicas pelo método de dessecação. Fitopatologia Brasileira 5:461-462. 1970.

TAKATSU, A. Erwinias do grupo carotovora no Brasil. Fitopatologia Brasileira 8:535-536. 1983.

TAKATSU, A., MELO, S. \& GARCIA, E.J. Fruto do pimentão como meio parcialmente seletivo para o isolamento de Erwinia carotovora. Fitopatologia Brasileira 6:550-551. 1981.

THOMSON, S.V., HIDELBRAND, D.C. \& SCHROTH, M.N. Identification and nutritional diferentiation of the Erwinia carotovora and Erwinia chrysanthemi. Phytopathology 71:1037-1042. 1981. 